OPEN ACCESS

Edited by:

Adelaida María Castro Sánchez, University of Almería, Spain

Reviewed by: Inmaculada Lara Palomo,

University of Almería, Spain Antonio Tessitore,

Foro Italico University of Rome, Italy

*Correspondence: Pedro Gil-Madrona Pedro.Gil@uclm.es

Specialty section: This article was submitted to Movement Science and Sport Psychology, a section of the journal Frontiers in Psychology

Received: 25 January 2020 Accepted: 09 June 2020 Published: 17 July 2020

Citation: Gil-Madrona P, Gómez JL, Aguilar-Jurado MÁ and

Gutiérrez-Marín EC (2020) Appropriate Self-Perceived Behaviors in Primary Education Pupils During Sports Games.

Front. Psychol. 11:1528. doi: 10.3389/fpsyg.2020.01528

\section{Appropriate Self-Perceived Behaviors in Primary Education Pupils During Sports Games}

\author{
Pedro Gil-Madrona ${ }^{1,2 *}$, José Luis Gómez ${ }^{1,2}$, Miguel Ángel Aguilar-Jurado ${ }^{1,2}$ and \\ Eva Cristina Gutiérrez-Marín ${ }^{1,2}$
}

${ }^{1}$ Department of Physical Education, Faculty of Education, University of Castilla-La Mancha, Albacete, Spain, ${ }^{2}$ Department of Pedagogy, Faculty of Education, University of Castilla-La Mancha, Albacete, Spain

Based on the results obtained from primary education students-fifth and sixth graders - the aim of this work is to check the appropriate self-perceived behaviors during and at the end of the game. The study population was made up of 698 students from fifth and sixth grade in the Autonomous Region of Castilla-La Mancha (Spain). Data were collected through a questionnaire (scale) on the social skills of primary school students linked to the adequate skills when losing, the adequate skills when winning, and the adequate skills during the game. Study results revealed that analyzed behaviors vary, depending on the moment of the game, being it more frequently during the development of the game than when losing or winning.

Keywords: appropriate behaviors, games and sports, primary education, self-perception, interactive skills of students

\section{INTRODUCTION}

The uses of appropriate behaviors are considered essential and challenging factors to manage pedagogical tasks in the educational field, being necessary the coincidence of several additional components (such as symbiotic student-family relationships or the importance awarded to teachers) for accurately achieving the expected success (Giraldo and Mera, 2014). It is also necessary to be aware of the existence of disruptive behaviors, understanding them as the set of conducts that deteriorate or interrupt the teaching and learning processes developed within the classrooms (Ramírez and Justicia, 2006). For Torrego and Moreno (2003), "disruption is the background music of most of our classrooms" (p. 129). Disruptive behaviors emerge from various phenomena (Moreno et al., 2007), for example, particular competitive environments, rigidity, or the lack of attention to special educational needs students (Mateo, 2014). For the latter author, disruptive behaviors usually manifest themselves in:

1. Children whose behavior management is not appropriate;

2. Children whose parents are excessively permissive where the child begins the process of socialization, particularly in early childhood; and

3. The school context, especially when teachers do not set clear limits regarding what is allowed and what is not allowed.

Appropriate behavior is still an unconventional topic, and the literature on the subject is still not yet abundant. Thus, students' behaviors within the classrooms have become one of the main focus 
of attention in the educational field. The earlier mentioned fact is due to the influence generated on teachers' capacities to control the behaviors that students exhibit in classrooms (LópezGonzález, 2015). Concerning behavior control, it is necessary to highlight the work of Barreda Gómez (2012) where they affirmed that, at schools, students should be taught a series of actions to generate an ideal environment for knowledge acquisition through the curricular area of physical education.

Esteban et al. (2012) pointed out the existence of differences on the variety of disruptive behaviors happening in the physical education area, for example, murmuring in class while the teacher explains a particular topic, laughing, speaking loudly, or even chewing gum. For an efficient intervention, it is essential to be aware of the causes or factors originating such phenomena. In this sense, Valdivia (2010) argues that disruptive behaviors do usually occur due to four fundamental factors:

(1) Sociodemographic. The sociodemographic factors affecting students can be gender, living in precarious conditions, or having a one-parent family. Regarding disruptive levels of behaviors in students, it is necessary to demystify race and ethnicity.

(2) Educational. Five percent of disruptive behaviors are attributed to the lack of preventive measures, the inadequate regulations to regulate conflicts, and some other self-control factors. Additionally, $9 \%$ of the problems are attributed to school reasons such as the inadequate attitude of teachers.

In the same line of thought, Valdés et al. (2009) and Esteban et al. (2012) stated that behaviors revealed by students in the physical education classroom correlated with the teaching methods implemented by teachers-being those instructional models based on the mere reproduction of the main predictors of undisciplined behaviors.

(3) Familiar. Thirty-two percent of disruptive behaviors are attributed to family causes such as divorced parents, the excessive amount of time spent at work, permissiveness, overprotection, and so on. In consequence, parents' involvement in the education of their descendants reveals itself essential for the determination of ulterior student's behaviors in the classroom. Such an explanation of the factor is because parents who are involved in the development of their children provide more significant and emotional features by consistently monitoring children's activities (Moreno et al., 2007).

(4) Social. Ten percent of disruptive behaviors are attributed to social factors influencing on them-advertising, radio, television, and lack of appropriate behavioral patterns. The undisciplined behavior of the students has an influential relationship with the social environment they belong to.

Particularly to novel in-service teachers, one of the aspects worrying most to professionals linked to the area of physical education are the behaviors disrupting their lessons. The reason for such concern is those pupils with disruptive behavior have difficulty achieving learning goals and objectives along with the training process (Esteban et al., 2012). For this particular motive, there are significant interests for the understanding of those cognitive mechanisms related to the undisciplined and unruled behaviors interfering in the physical education classroom for treating the problem more holistically (Siedentop, 1991; Lewis, 2001; Moreno et al., 2007). Hence, behavior improves when the interventions are designed and implemented to favor such demeanor in the physical education programs (Buceta, 2004; Vidoni and Ward, 2009; Samalot-Rivera and Porretta, 2013; Monjas Aguado et al., 2015; Crespo et al., 2016; López et al., 2016; Saiz Panadero et al., 2016). Besides, it is interesting to highlight the existence of models focused on improving these skills.

Apropos of student's behavior, the Hellison (1995) Social Responsibility Model proposes five levels of behavioral development: responsibility, irresponsibility, self-control, involvement, and interest. Additionally, the Sports Education Model (Siedentop et al., 2004) integrates the skills, strategies, and aspects of sports culture in contexts where the students participate in environments highlighting fair play, equity, and inclusion (Wallhead and O'sullivan, 2007). Concerning teamwork, and as the fundamental background to this research, the work of González et al. (2014) is to be highlighted, whose research goal analyzed the attitude control in players from a football team-concluding that psychological interventions may improve attitudinal behaviors for coping with competitiveness, granting more significant optimization to sports performance.

In summary, Ward and Barrett (2002) and Vidoni and Ward (2006) concluded that additional studies in the field are needed to consistently demonstrate-or not-if the behavioral conducts taught and performed during the physical education lessons can be maintained and generalized to other contexts. To contribute to such discovering, based on the obtained outcomes, the present research aims at checking the appropriate selfperceived behaviors in fifth and sixth graders, during and at the end of the game.

\section{MATERIALS AND METHODS}

\section{Sample}

As displayed in Table 1, the study population consisted of 698 students of the fifth and sixth grade of primary education in the Autonomous Region of Castilla-La Mancha (Spain). The sample's average age was 10.53 years (standard deviation $=0.74$ ). The stratified random sampling $(p=q=50 \%$; error $=3.71 \%$; confidence level $=95 \%$ ) is carried out according to the following parameters: gender (51\% girls; $49 \%$ boys), grade $(53.44 \%$ fifth graders; $46.56 \%$ sixth graders), and type of school $(88.68 \%$ of public schools; $11.32 \%$ semipublic schools).

\section{Procedure}

Having gotten the corresponding ethical permits for carrying out the investigation (from the management team, the head of studies, and the parents and teachers associations), data collection was managed through a questionnaire (scale). The scale items were about the social skills of primary education students concerning the appropriate abilities or skills to lose, the appropriate skills to win, the appropriate skills during the game, the social skills, and the skills linked to fair play.

The questionnaire-implemented during May and June 2018-was filled out individually at the beginning of the first physical education lesson. Hence, before the questionnaire implementation, students were not response-conditioned 
TABLE 1 | Sample distribution by gender, grade, and type of school.

\begin{tabular}{lcc}
\hline Stratification & Frequencies & Percentages \\
\hline Gender & 342 & 49 \\
Boys & 356 & 51 \\
Girls & 698 & 100 \\
Total & & \\
Grade & 373 & 53.44 \\
5 & 325 & 46.56 \\
6 & 698 & 100 \\
Total & & \\
Type of school & 619 & 88.68 \\
Public & 79 & 11.32 \\
Semipublic & 698 & 100 \\
Total & & \\
\hline
\end{tabular}

TABLE 2 | Statistics representing scale reliability.

\begin{tabular}{lcc}
\hline Dimensions & No. of items & Cronbach's $\boldsymbol{\alpha}$ \\
\hline DAP & 5 & 0.731 \\
DAG & 5 & 0.708 \\
DADJ & 5 & 0.696 \\
DJJ & 5 & 0.689 \\
HS & 12 & 0.733 \\
Total scale & 32 & 0.883 \\
\hline
\end{tabular}

but previous-experience encouraged. Explanations and the completion of the questionnaire were approximately $15 \mathrm{~min}$. During questionnaire implementation, the corresponding teaching staff on each of the selected educational centers supervised the participants. Before task accomplishing, accurate introductory explanations were provided on the questionnaire (objectives, scope, relevance, dissemination, completion, etc.). After task explanations, participants were asked to indicate the degree of agreement or disagreement on the items reflected on the questionnaire. Once the information was collected and considered relevant by the research group, its scientific dissemination was agreed.

\section{Instrument}

For the elaboration of the scale, it was necessary to decide on which dimensions and items would be suitable to include as critical elements for the explanation of social skills appropriate to the game in fifth and sixth graders. Literature review on the subject provided relevant information (Table 2) based on the research of the following authors: Hellison (2003), Siedentop et al. (2004), Escartí et al. (2005), Gil-Madrona (2008), SamalotRivera (2013), López et al. (2016), and Saiz Panadero et al. (2016). There was also considered additional research supported by the Hellison's (2003) Social Responsibility Model, the Code of Conduct for Fair Play by Siedentop et al. (2004), and the Units of the Teaching Curriculum of Appropriate Sports Conduct of Samalot-Rivera (2007).

The exploratory factor analysis on the instrument was previously published in the work of Gutiérrez-Marín et al. (2017). Design results ended on a weighted-out scale including a total number of 32 Likert response items of 5 marks displaying the subsequent ponderation: 1 = never, 2 = seldom, 3 = occasionally, $4=$ almost always, and $5=$ always. From a theoretical perspective, and adding the corresponding scores, the items were also grouped considering the five dimensions [items 1-15 in this research; items 16-32 in Gutiérrez-Marín et al. (2019)]:

1. Items 1-5: Appropriate Skills to Lose (DAP);

2. Items 6-10: Appropriate Skills to Win (DAG);

3. Items 11-15: Appropriate Skills During the Game (DADJ);

4. Items 16-20: Fair-Play Skills (DJJ);

5. Items 21-32: Social Skills (HS).

As previously mentioned, and in addition to the analysis of the displayed items (Table 2), the questionnaire was also designed for the collection and classification of questions concerning some fundamental characteristics of the individuals within the research sample (gender, grade, type of school, and age).

Apropos of the validity of the scale, a confirmatory factor analysis was carried out based on previous research by GutiérrezMarín et al. (2017). Nevertheless, the likelihood function adjusted the theoretical model defined in the instrument. Results on the goodness of fit from the statistical model on the sample revealed themselves satisfactory (Table 3)-considering different criteria such as the comparative fit index (CFI), the Tucker-Lewis Index (TLI), the root mean square error of approximation (RMSA), and the standardized root mean square residual (SRMR). Hence, the validity of the instrument used was consistently verified.

\section{Statistical Analysis}

Based on frequencies (percentages) of the items on the scale, a global-behavior study on the individuals was carried out through descriptive analysis. After that, inferential tests were performed to determine the possible existence of significant differences in the dimensions of the scale stratified by gender, grade, and school. For this purpose, a Mann-Whitney (M-W) test was applied. The existence of significant differences in the stratified dimensions was also analyzed at different time points-during and after the game; globally and stratified by gender, course, and school-using the Wilcoxon test for dependent samples.

In those cases in which significant differences were observed between the groups of analysis, a post hoc analysis was performed. Post hoc was based on the study of the magnitude and sign of the average ranges of the scores obtained. The reason for such selection was to verify which groups of subjects gathered higher or lower scores on the scrutinized dimensions and, therefore, generated the significant differences in both $\mathrm{M}-\mathrm{W}$ and Wilcoxon tests. The Rosenthal $r$ criterion pinpointed accuracy on the

TABLE 3 | Confirmatory factor analysis on the scale.

\begin{tabular}{ll}
\hline Goodness of fit & Value \\
\hline CFI & 0.915 \\
TLI & 0.92 \\
RMSA & 0.047 \\
SRMR & 0.048
\end{tabular}


size of the effect. All of the estimations and hypothesis tests were practiced using a $95 \%$ confidence level. Statistical programs utilized for the analyses were both SPSS version 22 (licensed by Universidad de Castilla-La Mancha) and R (open source).

\section{RESULTS}

This part exhibits the results related to the appropriate behaviors (i) when winning, (ii) when losing, and (iii) during the games. It is relevant to consider the postponed presentation in an ulterior publication work about some of the results from this study concerning fair-play and social skills.

\section{Appropriate Behaviors in Games and Sports: Three-Dimensional Overall Results}

The overall behavior of the students revealed throughout the different scales of the instrument was quite similar. Generally, participants agreed always or almost always with the affirmations of the items in each of the analysis scales. Thereafter, some relevant results are displayed in a hierarchical way in the following (a), (b), and (c) paragraphs, as well as in Table 4:

1. On the Appropriate Losing Skills (DAP) scale, Item 5 is noticeable ("During physical education lessons, do you respect self-materials (e.g., tennis racket) and the materials of other classmates?"), because $81.1 \%$ of the students answered always.

2. On the DAG scale, both Item 6 ("During physical education lessons, do you avoid criticizing the one or the ones who lost?") and Item 9 ("During the physical education lessons, do you show appreciation to opponents and teammates?") are noticeable, because $55.3 \%$ and $51.9 \%$ of answers from participants, respectively, were observed on the always marking item.

TABLE 4 | Reaction percentages by scale and items.

\begin{tabular}{ccccccc}
\hline \multirow{2}{*}{ Scales } & \multirow{2}{*}{ Items } & \multicolumn{5}{c}{$\%$} \\
\cline { 3 - 7 } & & Never & Seldom & Occasionally & Almost always & Always \\
\hline DAP & Item 1 & 5.9 & 7.2 & 23.6 & 36.4 & 26.9 \\
& Item 2 & 1.3 & 3.4 & 14.2 & 34.4 & 46.7 \\
& Item 3 & 5.4 & 8.5 & 17.9 & 30.9 & 37.2 \\
& Item 4 & 13.3 & 7.4 & 12.8 & 29.5 & 37 \\
& Item 5 & 1.7 & 0.4 & 5.4 & 11.3 & 81.1 \\
DAG & Item 6 & 7.3 & 3.7 & 11 & 22.6 & 55.3 \\
& Item 7 & 12.5 & 5.4 & 14.2 & 24.8 & 43.1 \\
& Item 8 & 3.4 & 5.3 & 14.1 & 353 & 41.8 \\
& Item 9 & 2.3 & 3.2 & 15.7 & 27 & 51.9 \\
& Item 10 & 8.6 & 4.7 & 14.8 & 277 & 44.1 \\
DADJ & Item 11 & 0.9 & 1.3 & 5.5 & 25.3 & 67.1 \\
& Item 12 & 3.7 & 5 & 15.9 & 39.1 & 36.2 \\
& Item 13 & 2.3 & 2.7 & 10.5 & 28 & 56.5 \\
& Item 14 & 3.3 & 2.7 & 8.6 & 33.6 & 51.8 \\
& Item 15 & 2.4 & 1.4 & 9 & 20.4 & 66.7
\end{tabular}

3. On the DADJ scale, both Item 11 ("During physical education lessons, do you follow the rules of the game at all times?") and Item 15 ("During physical education lessons, are you a good member of the team and work in collaboration [not wanting to play alone]?") are noticeable, because $67.1 \%$ and $66.7 \%$ of participants (respectively) answered the Always marking item.

"During physical education lessons..." DAP: (1) Do you congratulate the winner on losing a match or game? (2) Do you stay calm and positive? (3) Do you ignore the mockery of other colleagues? (3) Do you avoid blaming your teammates for poor personal execution? (4) Do you respect self-materials (e.g., tennis racket) and the materials of other classmates? DAG: (6) Do you avoid criticizing the one(s) who lost? (7) Do you accept inputs from others when you win? (8) Do you provide suggestions to others in a respectful way? (9) Do you show appreciation to opponents and teammates? (10) Do you reward yourself and stay motivated without laughing at others? DADJ: (11) Do you follow the rules of the game at all times? (12) Do you make positive comments about the performance of others during the game? (13) Do you help others during the game if necessary (e.g., Help others to get up off the ground after a fall)? (14) Do you respect the skill level of others without belittling or making fun of them? (15) Are you a good team member working collaboratively (not wanting to play alone)?

\section{Appropriate Behaviors Concerning Gender, Grade, and Type of School}

Regarding gender variables, no additional explanation is required. The omission of such binomial elucidation is because, even though they were initially introduced in the research, male and female variables did not reveal significant differences from the answers manifested by the students analyzed from the research sample (Table 5).

Concerning the grades where the research was implemented, there were no statistically significant differences ( $95 \%$ confidence interval), in the behavior of the students in any of the implemented scales, as referenced in Table 6.

Concerning the variable type of school (Table 7), the behavior manifested by the students from each school (public, semipublic) differed on the scale DADJ. Taking as reference the $95 \%$ of confidence interval, M-W results were revealed as follows: (M$\mathrm{W}=-6.694, d f=1, p=0, r=0.2534)$. Specifically, participants belonging to public schools presented higher scores [average range $(\mathrm{DADJ})=366.56]$, when compared to participants tested at semipublic schools [average range $($ DADJ $)=207.41$ ].

\section{Appropriate Behaviors During and After the Game}

Statistically significant differences-95\% confidence intervalwere observed between the scales DADJ and DAP. Taking as reference the $95 \%$ of confidence interval, $\mathrm{M}-\mathrm{W}$ results were revealed as follows: (M-W $=-11.385, d f=1, p=0, r=0.4309)$. Particularly, the skills during the game were greater (average range: DADJ-DAP $>0=310.88$ ) than after the game when losing (average range: DADJ-DAP $<0=247.22$ ). There were 
TABLE 5 | Mann-Whitney (M-W) test on the scales by gender.

\begin{tabular}{|c|c|c|c|c|c|c|}
\hline M-W & Value & $d f$ & p-value & Average range: male & Average range: female & Effect size $(r)$ \\
\hline $\mathrm{DAP}^{\star}$ & -0.358 & 1 & 0.7204 & 346.73 & 352.16 & - \\
\hline$D_{A} G^{\star *}$ & -0.193 & 1 & 0.8474 & 349.99 & 347.07 & - \\
\hline DADJ ${ }^{\star \star *}$ & -0.821 & 1 & 0.4116 & 342.18 & 354.17 & - \\
\hline
\end{tabular}

*Appropriate losing skills. ${ }^{* *}$ Appropriate skills to win. ${ }^{* * *}$ Appropriate skills during the game.

TABLE 6 | Mann-Whitney (M-W) test on the scales by grade.

\begin{tabular}{|c|c|c|c|c|c|c|}
\hline M-W & Value & $d f$ & $p$-value & Average range: grade 5 & Average range: grade 6 & Effect size $(r)$ \\
\hline DAP & -0.45 & 1 & 0.6532 & 352.68 & 345.84 & - \\
\hline DAG & -0.057 & 1 & 0.9549 & 348.90 & 348.04 & - \\
\hline DADJ & -1.357 & 1 & 0.1748 & 338.95 & 359.47 & - \\
\hline
\end{tabular}

TABLE 7 | Mann-Whitney (M-W) test on the scales by type of school.

\begin{tabular}{|c|c|c|c|c|c|c|}
\hline M-W & Value & $d f$ & p-value & Average range: public & Average range: semipublic & Effect size $(r)$ \\
\hline DAP & -2.248 & 1 & 0.0246 & 355.60 & 301.74 & - \\
\hline DAG & -0.354 & 1 & 0.7238 & 347.54 & 356 & - \\
\hline
\end{tabular}

TABLE 8 | Wilcoxon test between scales during and after the game by gender.

\begin{tabular}{|c|c|c|c|c|c|c|c|c|c|c|c|c|}
\hline \multirow{2}{*}{$\begin{array}{l}\text { Gender } \\
\text { Wilcoxon }\end{array}$} & \multicolumn{6}{|c|}{ Boys } & \multicolumn{6}{|c|}{ Girls } \\
\hline & Value & $d f$ & $p$ & $\begin{array}{c}\text { Average } \\
\text { range: DADJ- } \\
\text { DAP }<0\end{array}$ & $\begin{array}{c}\text { Average } \\
\text { range: DADJ- } \\
\text { DAP > } 0\end{array}$ & Effect size $(r)$ & Value & $d f$ & $p$ & $\begin{array}{c}\text { Average } \\
\text { range: DADJ- } \\
\text { DAP <0 }\end{array}$ & $\begin{array}{c}\text { Average } \\
\text { range: DADJ- } \\
\text { DAP > } 0\end{array}$ & Effect size $(r)$ \\
\hline DADJ-DAP & -7.330 & 1 & 0 & 132.96 & 155.22 & 0.2774 & -8.860 & 1 & 0 & 112.62 & 158.63 & 0.3353 \\
\hline DADJ-DAG & -7.136 & 1 & 0 & 114.61 & 163.28 & 0.2701 & -8.181 & 1 & 0 & 104.04 & 160.12 & 0.3096 \\
\hline
\end{tabular}

also significant differences between DADJ and DAG. Taking as reference the $95 \%$ of confidence interval, $\mathrm{M}-\mathrm{W}$ results revealed as follows: $(\mathrm{MW}=-10.818 ; d f=1 ; p=0 ; r=0.4094)$. As in the previous comparison, the skills during the game were higher (average range: DADJ-DAP $>0=322.85$ ) than after this, in this case, when winning (average range: DADJ-DAP $<0=218.64$ ).

\section{Appropriate Behaviors-During/After Game-Considering Gender, Grade, Type of School}

As mentioned in the previous section, appropriate skills during the game revealed themselves more significant, when compared with the same skills after the game-either participant losing or winning on the activities. By gender, the highest scores in the skills during the game-concerning the skills "after the game" and "losing"-females achieved slightly higher (average range: DADJ-DAP $>0=158.63$ ), compared to males (average range: DADJ-DAP $>0=155.22$ ). However, in the case of after the game and winning, the highest scores in the skills during the game were somewhat higher in males (average range: DADJDAP $>0=163.28$ ), compared to females (average range: DADJDAP $>0=160.12$ ), as represented within Table 8 .

By academic year, the highest scores in the skills "during the game"-concerning the skills after the game and losingwere higher in the case of the fifth-grade students (average range: DADJ-DAP $>0=161.94)$, compared to sixth-grade students (average range: DADJ-DAP $>0=149.35$ ). This same circumstance did also occur "after the game" and "winning." The students of fifth grade presented higher skills during the game than after the game (average range: DADJ-DAG $>0=173.74$ ), when compared to sixth graders (average range: DADJDAG $>0=149.84$ ).

\section{DISCUSSION}

Once the present research study has reached the end, it can be observed how the analyzed behaviors may vary depending on the moment the game is being performed, appearing more considerable skills during the game than when losing or winning on it (Wang et al., 2015). Therefore, reference is to be made to Gil-Madrona (2008), who states that-along with the game or the activity-students need to be provided with structured guidelines allowing them learning and being respectful and careful. There are also significant statistical differences between the appropriate skills during the game and when losing-manifesting notable similarities in terms of gender and course. In terms of the type of school, and establishing the focus of attention on the appropriate skills during the game, considerable differences emerge as well-obtaining students from public schools with higher scores than those belonging to semipublic schools. There are similar research scales implemented in physical education (Llopis-Goig et al., 2011). 
Along with the implementation of the different instrument scales, the overall behavior of the students reveals quite similar. Most answers from participants were coincident on the items always or almost always - with the subsequent statistical reaffirmations of the items in each of the analysis scales. As reflected in other scales (Sánchez-Oliva et al., 2013), and because there are differences in skills during the game when losing and winning on it, the improvement of pupil's behavior on competitiveness is considered necessary. Competitive-behavior development influences participants' performance and fun development in sports, and in the long term, it also influences the way that children face daily challenges (Monjas Aguado et al., 2015). Through physical education, teachers have the opportunity to enhance both the emotional and cognitive domains in students. Yet what teachers promote will help to reflect and apply appropriate behaviors in physical education students (Lund and Kirk, 2010). In this particular sense, it is necessary to highlight the allocation of roles to students when implementing the games.

Role assignment is highly motivating for children, and they do enjoy these activities and learn with more enthusiasm when they adopt the roles fitting them better (Oberle, 2004). Using role games during physical education lessons produces countless opportunities for the intervention and demonstration of social and personal attributes (Hellison, 2003). Because role-playing is commonly used to teach appropriate behaviors during games and sports, teachers play an essential role in the development of students' social skills. When teachers teach and reinforce social skills, such as personal responsibility, they promote respect and help to others, as well as socialization (Gil-Madrona, 2003; Vidoni and Ulman, 2012; Gil-Madrona et al., 2014). The development of an adequate behavior of the game demands a more considerable educational effort, which needs constant work. Educating by transmitting values and skills appropriate to games and sports is part of the responsibility of schools, teachers, parents, and so on (Planchuelo, 2008; Flores-Aguilar et al., 2015). In this sense, it is necessary to highlight current research having as a goal the validation of questionnaires on the achievement and self-determination intentions, for example, the research carried out by Méndez et al. (2016).

\section{CONCLUSION}

In summary, the present work exposes how the instrument designed to measure appropriate behaviors during the game, associated with losing and winning skills, displays itself reliable and valid for its use in educational and research contexts. Thus, once the study is accomplished, it can be concluded that

\section{REFERENCES}

Barreda Gómez, M. S. (2012). El Docente Como Gestor del Clima del Aula. Factores a Tener en Cuenta. Trabajo Fin de Maìster, Universidad de Cantabria, Santander.

Buceta, J. M. (2004). Estrategias Psicológicas Para Entrenadores de Atletismo de Deportistas Jóvenes. Madrid: UNED. physical education teachers must place particular emphasis on the behaviors occurring during the game and, consequently, propose tasks and programs as accurate as possible. The design and implementation of such specific material will, undoubtedly, lead to interpersonal relationships during the teaching and learning process because it is along this process when interactions do mostly concur.

\section{Limitations and Suggested Lines of Research}

Study limitations arise from not having been selected a more extensive sample, for example, at the national level instead of regional. Another issue that we are striving at is not having addressed within this report some other dimensions such as collected fair-play and social skills. As a research landscape, the authors of the present article point out toward future studies considering formal and informal school environments. Undoubtedly, new research focusing goals on formal environments, such as secondary education, and informal environments, such as extracurricular activities, will end in quite valuable information (especially if researchers consider fields linked to players in regional and national competitions of junior and senior categories and include the social skills and fair-play factors in their research studies).

\section{DATA AVAILABILITY STATEMENT}

The datasets generated for this study are available on request to the corresponding author.

\section{ETHICS STATEMENT}

The studies involving human participants were reviewed and approved by the University of Castilla-La Mancha Research Ethics Committee and by the ethics committees of the schools participating in the study. Written informed consent to participate in this study was provided by the participants' legal guardian/next of kin.

\section{AUTHOR CONTRIBUTIONS}

PG-M contributed to the research design and development. JG contributed to the research writing and translation. MA-J contributed to the statistical analysis. EG-M contributed to the research implementation. All authors contributed to the article and approved the submitted version.

Crespo, P. C., Ayuso, A. P., and Gil-Madrona, P. (2016). Evaluación diagnóstica en la enseñanza conjunta de habilidades sociales y motrices en Educación Infantil. Opción 32, 505-525.

Escartí, A., Pascual, C., and Gutiérrez, M. (2005). Responsabilidad Personal y Social a Través de la Educación Física y el Deporte. Barcelona: Graó.

Esteban, R., Fernández, J. G., Díaz, A., and Contreras, O. R. (2012). Las conductas que alteran la convivencia en las clases de 
Educación Física. Rev. Int. Med. Ciencias Activ. Física Deporte 12, 459-472.

Flores-Aguilar, G., Grau, P., and Soler, S. (2015). Echando la vista atrás: la voz del profesorado de educación física sobre su trayectoria profesional en una escuela multicultural. Educ. Física Deportes 122, 88-98. doi: 10.5672/apunts.2014-0983. cat.(2015/4).122.10

Gil-Madrona, P. (2003). Diseño y Desarrollo Curricular en Educación Física y Educación Infantil. Wanceulen: Sevilla.

Gil-Madrona, P. (2008). La Educación Física y Los Deportes. Concreciones Prácticas de Educación en Valores. Granada: Editorial Magina.

Gil-Madrona, P., Samalot-Rivera, R. A., Gutiérrez-Marín, M. E., Ródenas, J. Y., and Ródenas, M. L. (2014). Improving social skills through physical education in elementary 4th year. Am. J. Sports Sci. Med. 2, 5-8. doi: 10.12691/ajssm-2-6a-2

Giraldo, L., and Mera, R. (2014). Clima social escolar: percepción del estudiante. Colombia Méd. 31, 23-27.

González, G., Del Castillo, O., and Romero, S. (2014). Análisis del control de la actitud en jugadores de un equipo de fútbol. J. Sport Health Res. 6, 241-252.

Gutiérrez-Marín, E., Gil-Madrona, P., Prieto-Ayuso, A., Aguilar-Jurado, M. A., and Samalot-Rivera, A. (2019). Conductas de juego justo y de habilidades sociales de los niños y niñas en las clases de educación física en Educación Primaria. Rev. Iberoamericana Psicol. Ejercicio Deporte 14, 126-130.

Gutiérrez-Marín, E., Gil-Madrona, P., Prieto-Ayuso, A., and Díaz-Suarez, A. (2017). Conductas apropiadas en Educación Física y el deporte en la escuela y validación de la escala. Cuadernos Psicol. Deporte 17, 99-110.

Hellison, D. (1995). Teaching Responsibility Through Physical Activity. Champaign, IL: Human Kinetics.

Hellison, D. (2003). Teaching Responsibility Through Physical activity, 2nd Edn. Champaign, IL: Human Kinetics.

Lewis, R. (2001). Classroom discipline and student responsibility: the students' view. Teach. Teach. Educ. 17, 307-319. doi: 10.1016/s0742-051x(00)00059-7

Llopis-Goig, R., Escarti, A., Pascual, C., Gutiérrez, M., and Marín, D. (2011). Fortalezas, dificultades y aspectos susceptibles de mejora en la aplicación de un Programa de Responsabilidad Personal y Social en Educación Física. Una evaluación a partir de las percepciones de sus implementadores. Cult. Educ. 23, 445-461. doi: 10.1174/113564011797330324

López, P. D. M., Prieto, A. A., Samalot, R. A., and Gil-Madrona, P. (2016). Evaluación de una propuesta extraescolar de conductas apropiadas en educación física y deportiva. Retos 30, 36-42.

López-González, G. E. (2015). Ambiente de Aprendizaje, Motivación y Disciplina en Las Clases de Educación Física. Tesis doctoral, Universidad de Valencia, Valencia.

Lund, J. L., and Kirk, M. F. (2010). Performance-Based Assessments for Middle and High School Physical Education, 2nd Edn. Champaign, IL: Human Kinetics.

Mateo, V. F. (2014). Conceptualización del Comportamiento Disruptivo en Niños y Adolescentes. Available at: https://www.redalyc.org/pdf/3457/345744747007. pdf (accessed July 20, 2017).

Méndez, G. A., Cecchini, E. J., Fernández, R. J., and Méndez, A. D. (2016). Metas de logro $3 \times 2$, motivación autodeterminada y satisfacción con la vida en Educación Secundaria. Rev. Psicodidáctica 21, 150-156. doi: 10.1016/j.psicod.2017.05.001

Monjas Aguado, R., Ponce, G. A., and Gea, F. J. (2015). La transmisión de valores a través del deporte. Deporte escolar y deporte federado: relaciones, puentes y posibles trasferencias. Retos 28, 276-284.

Moreno, J., Cervelló, E., Martínez, C., and Alonso, N. (2007). Los comportamientos de disciplina e indisciplina en Educación Física. Rev. Iberoamericana Educ. 44:167.

Oberle, A. P. (2004). Understanding public land management through roleplaying. J. Geogr. 103, 199-210. doi: 10.1080/00221340408978601

Planchuelo, L. (2008). Intervención y Evaluación del Desarrollo Moral en Educación Física en Primaria. Tesis Doctoral, Universidad de Málaga, Málaga.

Ramírez, S., and Justicia, F. (2006). El maltrato entre escolares y otras conductas problema para la convivencia. Rev. Electrón. Investig. Psicoeduc. 9, 265-290.
Saiz Panadero, M., Prieto, A. A., Gutiérrez, M. E., and Gil-Madrona, P. (2016). Evaluación inicial en $6^{\text {circ }}$ curso de primaria de las habilidades sociales y propuesta didáctica de intervención en la Educación Física escolar. Sport TK Rev. Euroamericana Ciencias Deporte 5, 65-74.

Samalot-Rivera, A. (2007). The Effects of a Social Skill Instruction on the Sport and Game Related Behaviors of Children and Adolescents with Emotional or Behavioral Disabilities. Doctoral Dissertation, The Ohio StateUniversity, Columbus, $\mathrm{OH}$.

Samalot-Rivera, A. (2013). Modelos a utilizar para la enseñanza de valores y destrezas sociales apropiadas en la Educación Física y el Deporte: una revisión de literatura. Available online at: https://www.efdeportes.com/efd184/ la-ensenanza-de-valores-y-destrezas-sociales.htm

Samalot-Rivera, A., and Porretta, D. (2013). The influence of social skills instruction on sport and game related behaviours of students with emotional or behavioural disorders. Phys. Educ. Sport Pedagogy 18, 117-132. doi: 10.1080/ 17408989.2011.631004

Sánchez-Oliva, D., Sánchez-Miguel, P.-A., Leo, F.-M., Amado, D., and GarcíaCalvo, T. (2013). Desarrollo y validación de un cuestionario para analizar la percepción de comportamientos positivos en las clases de educación física. Cult. Educ. 25, 495-507. doi: 10.1174/113564013808906843

Siedentop, D. (1991). Developing Teaching Skills in Physical Education, 3rd Edn. Mountain View, CA: Mayfield.

Siedentop, D., Hastie, P. A., and Van der Mars, H. (2004). Complete Guide to Sport Education, 2nd Edn. Champaign, IL: Human Kinetics.

Torrego, J. C., and Moreno, J. M. (2003). Convivencia y Disciplina en la Escuela. El aprendizaje de la Democracia. Madrid: Alianza.

Valdés, A., Martín, M., and Sánchez, P. (2009). Participación de los padres de alumnos de educación primaria en las actividades académicas de sus hijos. Rev. Electrón. Investig. Educ. 11, 1-17.

Valdivia, J. (2010). El comportamiento disruptivo del escolar en clases de Educación Física. Rev. Electrón. Efdeportes 143, 77-83.

Vidoni, C., and Ulman, J. D. (2012). The fair play game: promoting social skills in physical education. Strategies 25, 26-30. doi: 10.1080/08924562.2012.1059 2149

Vidoni, C., and Ward, P. (2006). Effects of a dependent group-oriented contingency on middle school physical education students' fair play behaviors. J. Behav. Educ. 15, 81-92. doi: 10.1007/s10864-006-9012-z

Vidoni, C., and Ward, P. (2009). Effects of fair play instruction on student social skills during a middle school sport education unit. Phys. Educ. Sport Pedagogy 14, 285-310. doi: 10.1080/17408980802225818

Wallhead, T., and O'sullivan, M. (2007). A didactic analysis of content development during the peer teaching tasks of a sport education season. Phys. Educ. Sport Pedagogy 12, 225-243. doi: 10.1080/1740898070161017

Wang, Y., Yang, L.-Q., Li, S., and Zhou, Y. (2015). Game theory paradigm: a new tool for investigating social dysfunction in major depressive disorders. Front. Psychiatry 6:128. doi: 10.3389/fpsyt.2015.00128

Ward, P., and Barrett, T. (2002). A review of behavioral analysis research in physical education. J. Teach. Phys. Educ. 21, 242-266. doi: 10.1123/jtpe.21. 3.242

Conflict of Interest: The authors declare that the research was conducted in the absence of any commercial or financial relationships that could be construed as a potential conflict of interest.

Copyright $\odot 2020$ Gil-Madrona, Gómez, Aguilar-Jurado and Gutiérrez-Marín. This is an open-access article distributed under the terms of the Creative Commons Attribution License (CC BY). The use, distribution or reproduction in other forums is permitted, provided the original author(s) and the copyright owner(s) are credited and that the original publication in this journal is cited, in accordance with accepted academic practice. No use, distribution or reproduction is permitted which does not comply with these terms. 